\title{
Phosphate-solubilizing bacteria as inoculants for agriculture: use of updated molecular techniques in their study
}

\author{
José Mariano IGUAL ${ }^{\text {a* }}$, Angel VAlverde ${ }^{\mathrm{a}}$, Emilio CERVANTES ${ }^{\mathrm{a}}$, Encarna VeláZquez \\ a Instituto de Recursos Naturales y Agrobiología, Consejo Superior de Investigaciones Científicas, \\ Apartado 257, 37071 Salamanca, Spain \\ ${ }^{\mathrm{b}}$ Departamento de Microbiología y Genética, Edificio Departamental, Universidad de Salamanca, 37007 Salamanca, Spain
}

(Received 18 December 2000; revised 3 July 2001; accepted 30 August 2001)

\begin{abstract}
The use of phosphate-solubilizing bacteria (PSB) as inoculants simultaneously increases P uptake by the plant and crop yield. A method to isolate efficient strains, an overview of some updated molecular techniques useful in their characterization (16S rRNA sequencing, LMW RNA profiles, TP-RADP and rep-PCR fingerprinting) and a method for obtaining strain-specific DNA probes will be briefly explained. These methodologies are not time-consuming and, in general, do not require sophisticated equipment.
\end{abstract}

phosphate-solubilizing bacteria / 16S rRNA / LMW RNA / TP-RAPD / rep-PCR / DNA probes

Résumé - Les bactéries qui solubilisent les phosphates comme inoculants en agriculture : utilisation de techniques moléculaires récentes pour leur étude. L'utilisation de bactéries qui solubilisent les phosphates comme inoculants augmente en même temps l'absorption de cet élément par la plante ainsi que le rendement des cultures. Cet article contient une brève revue des techniques récentes de biologie moléculaire utilisées pour caractériser ces bactéries (séquençage du 16S RNA, profils de LMW RNA, et empreintes par TP-RAPD et rep-PCR). On présente aussi une méthode d'isolation de souches efficientes pour la solubilisation du phosphate et une méthode pour obtenir des sondes d'ADN spécifiques des souches. Il s'agit de méthodes rapides qui, en général, n'ont pas besoin d'un équipement sophistiqué.

bactérie dissolvant les phosphates / 16S rARN / LMW RNA / TP-RAPD / rep-PCR / sonde ADN

\section{INTRODUCTION}

Phosphorus is one of the major plant nutrients limiting plant growth. Most agricultural soils contain large reserves of $\mathrm{P}$, a considerable part of which has accumulated as a consequence of regular applications of chemical fertilizers. However, a large proportion of soluble inorganic phosphate added to soil is rapidly fixed as insoluble forms soon after application and becomes unavailable to plants [51]. Phosphorus fixation and precipitation in soil is generally highly dependent on $\mathrm{pH}$ and soil type. In acid soils, free oxides and hydroxides of $\mathrm{Al}$ and $\mathrm{Fe}$ fix $\mathrm{P}$, while in alkaline soils it is fixed by $\mathrm{Ca}$, causing a low efficiency of soluble P fertilizers. The

Communicated by Jean-Jacques Drevon (Montpellier, France)

* Correspondence and reprints

igual@gugu.usal.es 
calcium superphosphate fertilizer, which contains about $15 \%$ of phosphorus pentoxide, normally loses its available $\mathrm{P}$ proportion when it comes in contact with soil minerals containing calcium carbonates [31].

A substantial number of bacterial species, mostly those associated with the plant rhizosphere, may exert a beneficial effect upon plant growth [17]. This group of bacteria has been termed "plant growth promoting rhizobacteria" or PGPR [28] and, among them, some phosphate-solubilizing bacteria (PSB) are already used as commercial biofertilizers for agricultural improvement $[51,58]$.

Although plant growth promoting rhizobacteria occur in soil, usually their numbers are not high enough to compete with other bacteria commonly established in the rhizosphere. Therefore, for agronomic utility, inoculation of plants by target microorganisms at a much higher concentration than those normally found in soil is necessary to take advantage of their beneficial properties for plant yield enhancement. Root colonization is an important trait of rhizobacteria and can be strain-specific. Thus, to screen natural resources for better strains, reliable identification and detection methods are needed.

This paper presents, in a concise way, the rationale for plant inoculation with PSB, methods for screening and selecting elite strains of PSB, some updated molecular techniques to identify them, and a practical approach to obtaining DNA probes as useful tools for studying their behavior in soil.

\section{THE RATIONALE FOR PLANT INOCULATION WITH PSB}

Ectorhizospheric strains from pseudomonads and bacilli, and endosymbiotic bacteria from rhizobia have been described as effective phosphate solubilizers. The production of organic acids is considered as the principal mechanism for mineral phosphate solubilization in bacteria. This assumption has been corroborated by cloning of two genes involved in gluconic acid production: PQQ synthase [18, 32, 52] and gabY [3] genes. Gluconic acid is the principal organic acid produced by Pseudomonas sp. [26], Erwinia herbicola [32], Pseudomonas cepacia [19] and Burkholderia cepacia [51]. Rhizobium leguminosarum [24], Rhizobium meliloti [22] and Bacillus firmus [4] produce noticeable amounts of 2-ketogluconic acid. Other organic acids, such as lactic, isovaleric, isobutyric, acetic, glycolic, oxalic, malonic and succinic acids are also generated by different phosphate-solubilizing bacteria [51].

Beneficial effects of inoculation with phosphorus-solubilizing microorganisms to many crop plants have been described by numerous authors $[11,41,49,51,53,58$, 59]. Rhizobia are, perhaps, the most promising group of PSB on account of their ability to fix nitrogen symbiotically with legumes and the capacity of some strains for solubilizing insoluble inorganic phosphate compounds $[23,24]$. Several publications have demonstrated that phosphate-solubilizing strains of Rhizobium and Bradyrhizobium increase growth and $\mathrm{P}$ content of non leguminous as well leguminous plants $[2,6,7,43]$.

An alternative approach for the use of phosphate-solubilizing bacteria as microbial inoculants is the use of mixed cultures or co-inoculation with other microorganisms. In this regard, some results suggest a synergistic interaction between vesicular arbuscular mycorrhizae (VAM) and PSB which allows for better utilization of poorly soluble $\mathrm{P}$ sources $[14,16,27,44,47,60,61]$. Similarly, plant growth can be increased by dual inoculation with PSB and Azospirillum [1,5] or Azotobacter $[29,38]$.

\section{ISOLATION AND SELECTION OF PSB TO BE USED AS INOCULANTS}

Phosphate-solubilizing bacteria are isolated from rhizospheric samples by plating serial dilutions of rhizospheric soil extracts in Pikovskaya's solid medium [45]. That medium contains insoluble tri- or bi-calcium phosphate, allowing the detection of phosphate-solubilizer microorganisms by the formation of "halos" around their colonies. The addition of bromophenol blue, which produces yellow coloured halos around the colonies in response to the $\mathrm{pH}$ drop by the release of organic acids, or proton release in exchange for cation uptake, generates more reproducible results than with the simple halo method [21]. Although phosphate-solubilizing capability remains stable in most isolates, some strains show instability of this trait after several cycles of inoculation [24, 26]. Thus, the persistence of phosphate-solubilizing capacity after five or more subcultures should be the first criterion in selecting bacterial strains as microbial inoculants. Last of all, the identification of the most efficient phosphate solubilizers in vitro has to be done by quantifying their phosphate-solubilizing capacities in liquid cultures since, in some cases, there have been contradictory results between plate halo detection and phosphate solubilization in liquid cultures [51]. In this regard, a novel defined microbiological growth medium (NBRIP), which demonstrated about 3-fold higher efficiency compared to Pikovskaya's medium, has been formulated by Nautiyal [39].

After in vitro selection of the most efficient phosphate solubilizers, experiments should be carried out in order 
to know the effectiveness of the selected PSB strain(s) in association with the crop to be inoculated. The response of plant species or genotypes to inoculation often varies according to the bacterial strain used. Differential rhizosphere effect of crops in harboring a target PSB strain $[15,41]$ or even the modulation of the bacterial phosphate-solubilizing capacity by specific root exudates [20] may account for the observed differences.

Finally, field trials to test the performance of the inocula under real conditions are advisable since the efficiency of the inoculation varies with the soil type, $\mathrm{P}$ content of the soil, and other parameters [51]. For example, in the former Soviet Union a commercial biofertilizer under the name "phosphobacterin" was first prepared by incorporating Bacillus megaterium var. phosphaticum and widely used in the Soviet Union, East European countries and India with successful results [58]. However, it did not show the same efficiency in soils in the United States [57].

\section{CHARACTERIZATION OF PHOSPHATE- SOLUBILIZING BACTERIA}

Selected bacteria capable of persistent and high phosphate solubilization can be identified by phenotypic characterization or genotypic characterization. Phenotypic characterization relies mainly on numerous biochemical tests and was the traditional way to identify bacteria until the application of new molecular techniques for classification and description of microorganisms. Several commercial kits make this work easier. For example, the BIOLOG system can identify a wide range of soil bacteria (BIOLOG, California, USA; http://www.biolog.com), API 20NE system (bioMérieux, France; http://www.biomerieux.com) allows the identification of species among the pseudomonads group (including Acinetobacter) and the IdentBacillus system (Mikrokit Ibérica S.L., Spain; http://www.bme.es/ microkit) is able to differentiate between bacilli species. Nevertheless, to deal with the very complex and scarcely known microbial soil populations, molecular techniques are, without doubt, the most feasible tools.

Currently, the 16S rRNA sequence is by far the preferred phylogenetic marker used in microbial ecology [40]. As molecular chronometers, rRNA sequences have preserved their evolutionary history [68]. Highly conserved portions carry the information of early evolutionary events and changes that are more recent occur within less conserved positions or stretches. The degree of divergence of present day rRNA sequences gives an estimate of their phylogenetic distances. PCR amplification of bacterial 16S rRNA sequence is carried out using uni- versal bacterial primers, such as fD1 (5'CCGAATTCGTCGACAACAGAGTTTGATCCTGGCTCAG-3') and rD1 (5'-CCCGGGATCCAAGCTTAAGGAGGTGATCCAGCC-3') [67]. The obtained 16S rDNA amplicons are sequenced, and comparative analysis using comprehensive databases of bacterial $16 \mathrm{~S}$ rRNA gene sequences (http://rdp.cme.msu.edu/html; http://www.ncbi.nlm.nih.gov/Banklt) with appropriate software allows rapid identification of unknown bacteria based on their rRNA sequence data [34, 35]. However, the power of rRNA sequence based protocols resides at a low phylogenetic or taxonomic level of resolution, which is valuable for classifying bacteria at the genus level but is insufficient to classify bacteria at the (sub)species level $[13,25,68]$. Other more recent methods overcome this limitation.

A new, one-dimensional electrophoretic technique in polyacrylamide gels - termed staircase electrophoresis (SCE) - has permitted optimum separation of stable lowmolecular-weight (LMW) RNA [9]. The LMW RNA profiles include 5S rRNA and tRNA in prokaryotic microorganisms [42, 62, 63, 65] and 5.8S rRNA, 5S rRNA and tRNA in eukaryotic microorganisms [64]. These molecules are of great interest for taxonomic purposes due to their evolutionary conserved presence in all cells performing the same role (protein synthesis). This technique has already been applied to different groups of microorganisms: the family Rhizobiaceae [62, 65], Frankia [63], Clavibacter [42], and yeasts [64]. A distinguishing LMW RNA profile was obtained for each bacterial species assayed. From these works, we can currently affirm that all strains belonging to the same species display the same LMW RNA profile (both 5S rRNA and tRNA zones) and all species belonging to the same genus display the same 5S rRNA zone. Therefore, different genera can be distinguished by the 5S rRNA zone and different species can be distinguished by tRNA profiles (Fig. 1A).

More recently, a new PCR-based procedure, designated as Two Primers (TP)-RAPD fingerprinting, has been described to identify bacteria [50]. This method uses two primers, targeting partial sequences of the 16S rRNA gene of Escherichia coli, to obtain species-specific RAPD fingerprints (Fig. 1B). We have demonstrated that the different subspecies of Clavibacter michiganensis and Pectobacterium (Erwinia) carotovorum can be distinguished by such fingerprints (unpublished data). Therefore, both LMW RNA and TP-RAPD profiles can be used to identify bacteria at species and subspecies levels.

Finally, to study the biodiversity of these bacteria, strain-related profiles should be used. Three families of short intergenic repeated sequences have been found in 


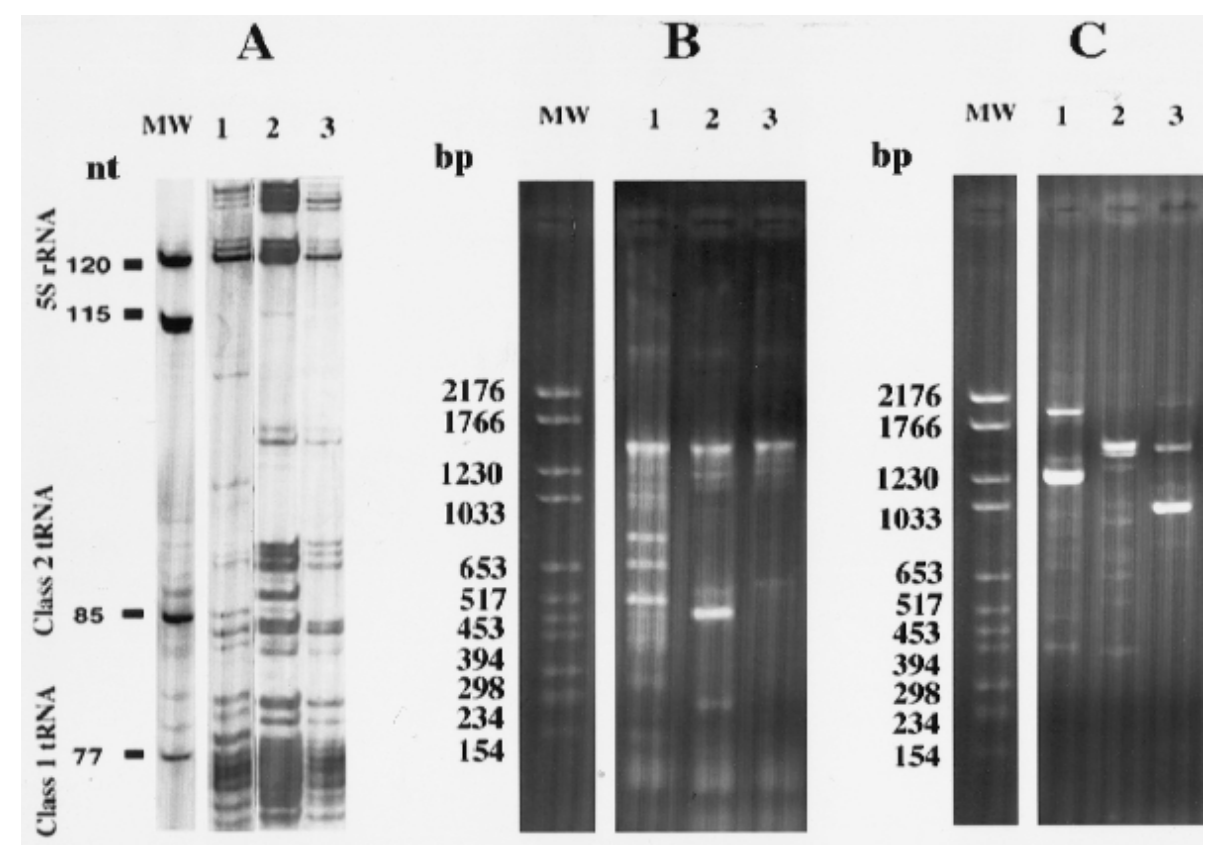

Figure 1. SCE LMW RNA profiles (A), TP-RAPD fingerprints (B) and REP-PCR fingerprints (C) of three phosphate-solubilizing rhizobia: lane 1, Sinorhizobium meliloti ATCC 9930 [22]; lane 2, Rhizobium leguminosarum ATCC 10004 ${ }^{\mathrm{T}}$ [24]; and lane 3, R. etli CFN $42^{\mathrm{T}}$ [Encarna Velázquez, personal communication]. Lane (MW) molecular size markers (ATCC: American Type Culture Collection; CFN: Centro de Fijación de Nitrógeno, Cuernavaca, Mexico).

eubacteria, namely REP (Repetitive Extragenic Palindromic elements), ERIC (Enterobacterial Repetitive Intergenic consensus) and BOX elements [66]. The PCR technique using specific primers corresponding to these ubiquitous and highly conserved repetitive DNA sequences (REP-, ERIC- and BOX-PCR; collectively known as rep-PCR) has demonstrated to generate strainspecific DNA fingerprints (Fig. 1C). This method is highly discriminating, allowing the differentiation of very closely related bacterial strains within species [10, $33,46,66]$. Hence, it provides a rapid and universal tool for assessing genomic variation in prokaryotic organisms. Studies on microbial ecology have particularly profited from these techniques $[12,30]$. rep-PCR is a universal tool for assessing genomic variations in prokaryotic organisms and is postulated to reflect the variability of the overall genome. No strain-, species-, or genus-specific primers are involved, allowing the use of only a few primers for the analysis of close as well as widely divergent bacteria. Moreover, no Southern blotting or DNA hybridization experiments are required to analyse the PCR products, and simple agarose gels are sufficient to separate them. Therefore, in studying micro- bial biodiversity, rep-PCR genomic fingerprinting is the least experimentally demanding method of choice, especially when complemented with computer-assisted pattern analysis.

\section{OBTAINING STRAIN-SPECIFIC DNA PROBES BY REP-PCR BASED TECHNIQUES}

Good competitive ability and high saprophytic competence are the major factors determining the success of a bacterial strain as an inoculant [55]. Studies to discover the competitiveness and persistence of specific microbial populations in complex environments, such as the rhizosphere, require methods for detecting and estimating the relative abundance of specific strains. The use of DNA probes for detection of soil-borne, specific phylogenetic groups has yielded promising results. However, laborious procedures are needed to obtain strain-specific probes $[8,36,54,56]$.

A method has been recently developed by Matheson et al. [37] to obtain strain-specific DNA probes for detecting bacteria in the environment based on rep-PCR 
techniques (Fig. 2), which produce, for each bacterial strain, a unique collection of DNA fragments that differ in size and, hence, in sequence. Briefly, the method employs amplification of genomic DNA by rep-PCR (Fig. 2a), followed by cloning of the amplified fragments in Escherichia coli competent cells through a plasmid vector (Fig. 2b). After purification (Fig. 2c), the cloned fragments are labeled with digoxigenine (DIG)-dUTP. Finally, these probes are screened against Southern blots of rep-PCR-amplified DNA fragments from both axenic bacterial cultures and environmental samples of microbial communities in order to identify those that are strain-specific (Fig. 2d). The high sensitivity of these probes allows the detection of extremely low numbers of target bacteria among a very complex and rich mixture of nontarget strains. These probes have sensitivity comparable to those of other PCR-based detection methods.

The method developed by Matheson et al. [37] has several advantages over other approaches for obtaining a strain-specific molecular probe: (i) the probe can be developed and used without any prior knowledge of the host strain or the probe sequence, (ii) the target sequence can be amplified from a mixed community without the need for strain-specific PCR primers, and (iii) a semiquantitative estimate of the number of target organisms present in a sample can be made by combining rep-PCR with a standard most-probable-number (MPN) procedure [48]. Studies on microbial ecology of phosphate-solubilizing bacteria may take advantage of the use of such probes. Due to the fact that many countries have strict regulations concerning the release of genetically engineered microorganisms, this methodology excels in applicability to those that use reporter genes, such as the $\beta$-glucoronidase gene (gus $A$ ) or the thermostable $\beta$-glucosidase gene $(\mathrm{celB})$ [55], as they imply genetic engineering of microorganisms.

\section{CONCLUSIONS}

Several recently developed molecular techniques allow us, in a rapid and easy way, to identify and detect phosphate-solubilizing bacteria. Studies on biodiversity, distribution and ecology of such bacterial populations in soil and plant rhizospheres may help to design efficient biofertilizers for each crop and soil type, which can contribute to improving farmers' profit by reducing the application of chemical fertilizers and, thus, to preserving environmental quality.

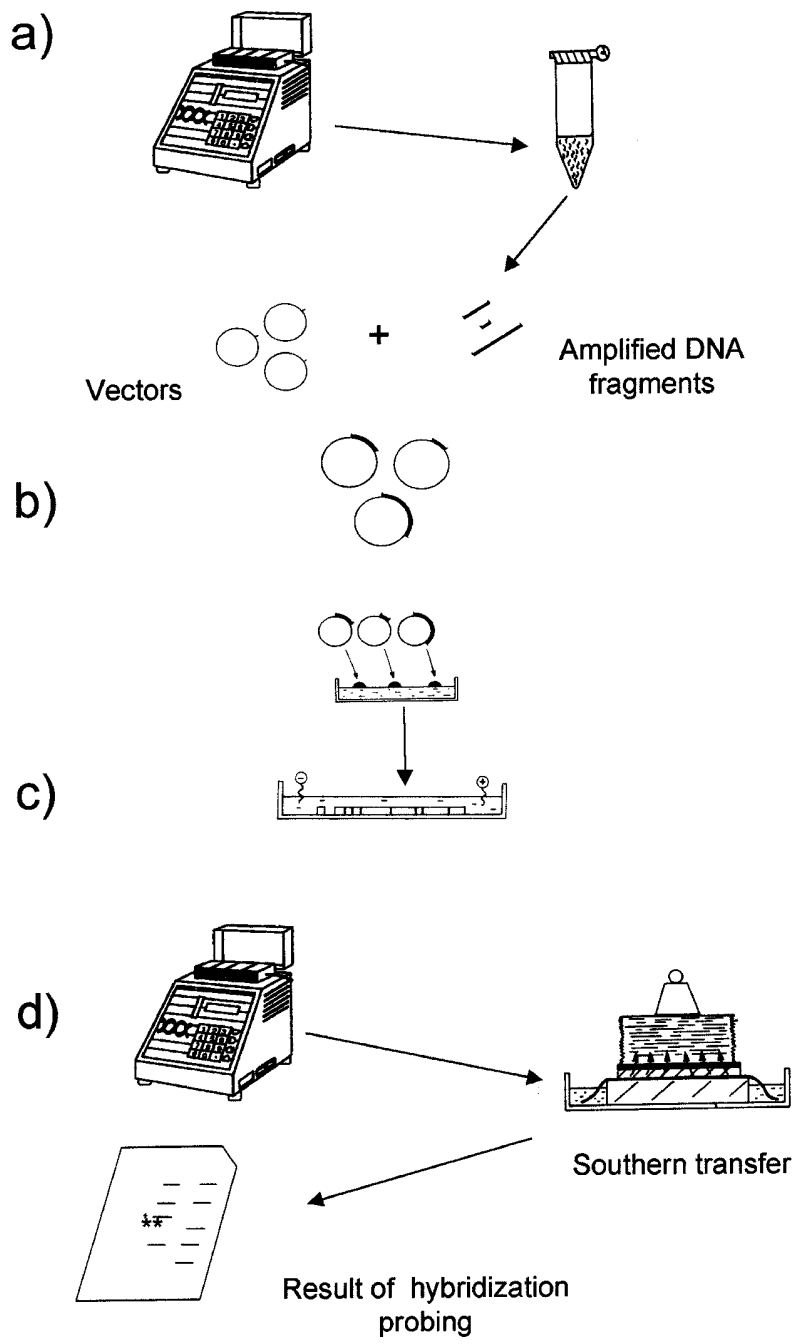

Figure 2. Diagram showing the different steps in obtaining strain-specific DNA probes as described by Matheson et al. [37]: (a) amplification of genomic DNA by rep-PCR using the primers REP1-R and REP2-I; (b) binding of rep-PCR products to pCRII vector and transformation of E. coli One Shot competent cells; (c) extraction of recombinant plasmids from transformed cells by alkaline lysis, digestion with EcoR1 to excise cloned fragments, purification of cloned fragments by electrophoresis and labeling with alkali-labile digoxigenin (DIG)dUTP; (d) screening of probes against Southern blots of repPCR amplified fragments from axenic cultures and also rhizospheric microbial communities in order to test the specificity of each probe.

\section{REFERENCES}

[1] Alagawadi A.R., Gaur A.C., Inoculation of Azospirillum brasilense and phosphate-solubilizing bacteria on yield of sorghum [Sorghum bicolor (L.) Moench] in dry land, Trop. Agric. 69 (1992) 347-350. 
[2] Antoun H., Beauchamp C.J., Goussard N., Chabot R., Lalande R., Potential of Rhizobium and Bradyrhizobium species as growth promoting bacteria on non-legumes: effect on radishes (Raphanus sativus L.), Plant and Soil 204 (1998) $57-67$.

[3] Babu-Khan S., Yeo C.T., Martin W.L., Duron M.R., Rogers R.D., Goldstein A., Cloning of a mineral phosphatesolubilizing gene from Pseudomonas cepacia, Appl. Environ. Microbiol. 61 (1995) 972-978.

[4] Banik S., Dey B.K., Available Phosphate content of an alluvial soil is influenced by inoculation of some isolated phosphate-solubilizing microorganisms, Plant and Soil 69 (1982) 353-364.

[5] Belimov A.A., Kojemiakov A.P., Chuvarliyeva C.V., Interaction between barley and mixed cultures of nitrogen fixing and phosphate-solubilizing bacteria, Plant and Soil 173 (1995) 29-37.

[6] Chabot R., Antoun H., Cescas M.P., Growth promotion of maize and lettuce by phosphate-solubilizing Rhizobium leguminosarum biovar phaseoli, Plant and Soil 184 (1996) 311-321.

[7] Chabot R., Beauchamp C.J., Kloepper J.W., Antoun H., Effect of phosphorus on root colonization and growth promotion of maize by bioluminiscent mutants of phosphate-solubilizing Rhizobium leguminosarum biovar phaseoli, Soil Biol. Biochem. 30 (1998) 1615-1618.

[8] Cooper J.E., Bjourson A.J., Streit W., Werner D., Isolation of unique nucleic acid sequence from rhizobia by genomic subtraction: Applications in microbial ecology and symbiotic gene analysis, Plant and Soil 204 (1998) 47-55.

[9] Cruz-Sánchez J.M., Velázquez E., Mateos P.F., Martínez-Molina E., Enhancement of resolution of low molecular weight RNA profiles by staircase electrophoresis, Electrophoresis 18 (1997) 1909-1911.

[10] de Bruijn F.J., Use of repetitive (Repetitive Extragenic Palindromic and Enterobacterial Repetitive Intergeneric Consensus) sequences and the polymerase chain reaction to fingerprint the genomes of Rhizobium meliloti isolates and other soil bacteria, Appl. Environ. Microbiol. 58 (1992) 2180-2187.

[11] Dubey S.K., Response of soybean (Glycine max) to biofertilizers with and without nitrogen, phosphorus and potassium on swell-shrink soil, Indian J. Agron. 43 (1998) 546-549.

[12] Dunbar J., White S., Forney L., Genetic diversity through the looking glass: effect of enrichment bias, Appl. Environ. Microbiol. 63 (1997) 1326-1331.

[13] Fox G.E., Wisotzkey J.D., Jurtshuk P., How close is close: $16 \mathrm{~S}$ rRNA sequence identity may not be sufficient to guarantee species identity, Int. J. Syst. Bacteriol. 42 (1992) 166-170.

[14] Frey-Klett P., Pierrat J.C., Garbaye J., Location and survival of mycorrhiza helper Pseudomonas fluorescens during establishment of ectomycorrhizal symbiosis between Laccaria bicolor and Douglas fir., Appl. Environ. Microbiol. 63 (1997) 139-144.
[15] Gaind S., Gaur A.C., Thermotolerant phosphate solubilizing microorganisms and their interactions in mung bean, Plant and Soil 133 (1991) 141-149.

[16] Garbaye J., Helper bacteria: a new dimension to the mycorrhizal symbiosis, New Phytol. 128 (1994) 197-210.

[17] Glick B.R., The enhancement of plant growth by freeliving bacteria, Can. J. Microbiol. 41 (1995) 109-117.

[18] Goldstein A.H., Liu S.T., Molecular cloning and regulation of a mineral phosphate solubilizing gene from Erwinia herbicola, Bio/Technology 5 (1987) 72-74.

[19] Goldstein A.H., Rogers R.D., Mead G., Mining by microbe, Bio/Technology 11 (1993) 1250-1254.

[20] Goldstein A.H., Braverman K., Osorio N., Evidence for mutualism between a plant growing in a phosphate-limited desert environment and a mineral phosphate solubilizing (MPS) rhizobacterium, FEMS Microbiol. Ecol. 30 (1999) 295-300.

[21] Gupta R., Singal R., Sankar A., Chander R.M., Kumar R.S., A modified plate assay for screening phosphate solubilizing microorganisns, J. Gen. Appl. Microbiol. 40 (1994) 255-260.

[22] Halder A.K., Chakrabartty P.K., Solubilization of inorganic phosphate by Rhizobium, Folia Microbiol. 38 (1993) 325-330.

[23] Halder A.K., Mishra A.K., Chakrabartty P.K., Solubilization of phosphatic compounds by Rhizobium, Indian J. Microbiol. 30 (1990) 311-314.

[24] Halder A.K., Mishra A.K., Bhattacharyya P., Chakrabartty P.K., Solubilization of rock phosphate by Rhizhobium and Bradyrhizobium, J. Gen. Appl. Microbiol. 36 (1990) 81-92.

[25] Hauben L., Vauterin L., Swings J., Moore E.R.B., Comparison of $16 \mathrm{~S}$ ribosomal DNA sequences of all Xanthomonas species, Int. J. Syst. Bacteriol. 47 (1997) 328-335.

[26] Illmer P., Schinner F., Solubilization of inorganic phosphates by microorganisms isolated from forest soil, Soil Biol. Biochem. 24 (1992) 389-395.

[27] Kim K.Y., Jordan D., McDonald G.A., Effect of phosphate-solubilizing bacteria and vesicular-arbuscular mycorrhizae on tomato growth and soil microbial activity, Biol. Fertil. Soils 26 (1998) 79-87.

[28] Kloepper J.W., Schroth M.N., Plant growth-promoting rhizobacteria on radishes, in: Gibert-Clarey, Tours Publishing, Proceedings of the IVth International Conference on Plant Pathogenic Bacteria, Vol. 2, Station de Phatologie Végétale et Phytobactériologie, INRA, Angers, France, 1978, pp. 879-882.

[29] Kundu B.S., Gaur A.C., Rice response to inoculation with $\mathrm{N}_{2}$-fixing and P-solubilizing microorganisms, Plant and Soil 79 (1984) 227-234.

[30] Lemenceau P., Corberand T., Gardan L., Latour X., Laguerre G., Boeufgras J.B., Alabouvette C., Effect of two plant species, flax (Linum usitatissinum L.) and tomato (Lycopersicon esculentum Mill.), on the diversity of soilborne populations of fluorescent pseudomonads, Appl. Environ. Microbiol. 61 (1995) 1004-1012. 
[31] Lindsay W.L., Chemical Equilibrium in soil, John Wiley and Sons, New York, 1979.

[32] Liu T.S., Lee L.Y., Tai C.Y., Hung C.H., Chang Y.S., Wolfram J.H., Rogers R., Goldstein A.H., Cloning of an Erwinia carotovora gene necessary for gluconic acid production and enhanced mineral phosphate solubilization in Escherichia coli HB101: Nucleotide sequence and probable involvement in biosynthesis of the coenzyme pyrroloquinoline quinone, J. Bacteriol. 174 (1992) 5814-5819.

[33] Louws F.J., Fulbright D.W., Stephens C.T., de Bruijn F.J., Specific genomic fingerprints of phytopathogenic Xanthomonas and Pseudomonas pathovars and strains generated with repetitive sequences and PCR, Appl. Environ. Microbiol. 60 (1994) 2286-2295.

[34] Ludwing W., Amann R., Martínez-Romero E., Schönhuber W., Bauer S., Neef A., Schleifer K.-H., rRNA based identification and detection systems for rhizobia and other bacteria, Plant and Soil 204 (1998) 1-19.

[35] Maidak B.L., Cole J.R., Lilburn T.G., Parker C.T. Jr., Saxman P.R., Farris R.J., Garrity G.M., Olsen G.J., Schmidt T.M., Tie J.M., The RDP-II (Ribosomal Database Project), Nucl. Acid. R. 29 (2001) 173-174.

[36] Manulis S.L., Valinsky A., Gabriel D.W., Sensitive and specific detection of Xanthomonas campestris pv. perlagonii with DNA primers and probes identified by random amplified polymorphic DNA analysis, Appl. Environ. Microbiol. 60 (1994) 4094-4099.

[37] Matheson V.G., Munakata-Marr J., Hopkins G.D., McCarty P.L., Tiedje J.M., Forney L.J., A Novel Means to Develop Strain-Specific DNA Probes for Detecting Bacteria in the Environment, Appl. Environ. Microbiol. 63 (1997) 2863-2869.

[38] Monib M., Hosny I., Besada Y.B., Seed inoculation of castor oil plant (Ricinus communis) and effect on nutrient uptake, Soil Biol. Conserv. Biosphere 2 (1984) 723-732.

[39] Nautiyal C.S., An efficient microbiological growth medium for screening phophate solubilizing microorganisms, FEMS Microbiol. Lett. 170 (1999) 265-270.

[40] Normand P., Orso S., Cournoyer B., Jeannin P., Chapelon C., Dawson J., Evtushenko L., Misra A.K., Molecular Phylogeny of the Genus Frankia and Related Genera and Emendation of the Family Frankiaceae, Int. J. Syst. Bacteriol. 46 (1996) 1-9.

[41] Pal S.S., Interaction of an acid tolerant strain of phosphate solubilizing bacteria with a few acid tolerant crops, Plant and Soil 198 (1998) 169-177.

[42] Palomo J.L., Velázquez E., Mateos P.F., GarcíaBenavides P., Martínez-Molina E., Rapid identification of Clavibacter michiganensis subspecies sepedonicus based on the stable Low Molecular Weight RNA (LMW RNA) profiles, Eur. J. Plant Pathol. 106 (2000) 789-793.

[43] Peix A., Rivas-Boyero A.A., Mateos P.F., RodríguezBarrueco C., Martínez-Molina E., Velázquez E., Growth promotion of chickpea and barley by a phosphate solubilizing strain of Mesorhizobium mediterraneum under growth chamber conditions, Soil Biol. Biochem. 33 (2001) 103-110.
[44] Piccini D., Azcón R., Effect of phosphate-solubilizing bacteria and vesicular arbuscular mycorrhizal (VAM) on the utilization of bayoran rock phosphate by alfalfa plants using a sand-vermiculite medium, Plant and Soil 101 (1987) 45-50.

[45] Pikovskaya R.I., Mobilization of phosphorus in soil in connection with the vital activity of some microbial species, Mikrobiologiya 17 (1948) 362-370.

[46] Rademaker J.L.W., Hoste B., Louws F.J., Kersters K., Swings J., Vauterin L., Vauterin P., de Bruijn F.J., Comparison of AFLP and rep-PCR genomic fingerprinting with DNA-DNA homology studies: Xanthomonas as a model system, Int. J. Syst. Evol. Microbiol. 50 (2000) 665-677.

[47] Ray J., Bagyaraj D.J., Manjunath A., Influence of soil inoculation with versicular arbuscular mycorrhizal (VAM) and a phosphate dissolving bacteria on plant growth and ${ }^{32} \mathrm{P}$ uptake, Soil Biol. Biochem. 13 (1981) 105-108.

[48] Recorbet G.C., Picard P., Normand P., Simonet P., Kinetics of the persistence of chromosomal DNA from genetically enginered Escherichia coli introduced into soil, Appl. Environ. Microbiol. 59 (1993) 4289-4295.

[49] Richardson A.E., Hadobas P.A., Hayes J.E., O'Hara C.P., Simpson R.J., Utilization of phosphorus by pasture plants supplied with myo-inositol hexaphosphate is enhanced by the presence of soil micro-organisms, Plant and Soil 229 (2001) $47-56$.

[50] Rivas R., Velázquez E., Valverde A., Mateos P.F., Martínez-Molina E., A two primers random amplified polimorphic DNA procedure to obtain polymerase chain reaction fingerprints of bacteria species, Electrophoresis 22 (2001) 1086-1089.

[51] Rodríguez H., Fraga R., Phosphate solubilizing bacteria and their role in plant growth promotion, Biotechnol. Adv. 17 (1999) 319-339.

[52] Rodríguez H., Gonzalez T., Selman G., Expression of a mineral phosphate solubilizing gene from Erwinia herbicola in two rhizobacterial strains, J. Biotechnol. 84 (2000) 155-161.

[53] Sarawgi S.K., Tiwari P.K., Tripathi R.S., Uptake and balance sheet of nitrogen and phosphorus in gram (Cicer arietinum) as influenced by phosphorus, biofertilizers and micronutrients under rainfed condition, Indian J. Agron. 44 (1999) 768-772.

[54] Seal S.E., Jackson L.A., Daniels M.J., Isolation of a Pseudomonas solanacearum-specific DNA probe by subtraction hybridization and construction of species-specific oligonucleotide primers for sensitive detection by the polymerase chain reaction, Appl. Environ. Microbiol. 58 (1992) 3751-3758.

[55] Sessitsch A., Hardarson G., de Vos W.M., Wilson K.J., Use of marker genes in competition studies of Rhizobium, Plant and Soil 204 (1998) 35-45.

[56] Springer N., Ludwig W., Hardarson G., A 23S RNA targeted specific hybridization probe for Bradyrhizobium japonicum, Syst. Appl. Microbiol. 16 (1993) 468-470.

[57] Smith J.H., Allison F.E., Soulides D.A., Phosphobacteria as a soil inoculant, Tech. US Dept. Agric. Bull. 1 (1962) 63-70. 
[58] Subba Rao N.S., Biofertilizers in Agriculture and Forestry, Oxford and IBH Publishing Co. Pvt. Ltd. New Delhi, 1993.

[59] Tomar R.K.S., Namdeo K.N., Ranghu J.S., Efficacy of phosphate solubilizing bacteria biofertilizers with phosphorus on growth and yield of gram (Cicer arietinum), Indian J. Agron. 41 (1996) 412-415.

[60] Toro N., Azcón R., Barea J.M., Improvement of arbuscular mycorrhiza development by inoculation of soil with phosphate-solubilizing rhizobacteria to improve rock phosphate bioavailability $\left({ }^{32} \mathrm{P}\right)$ and nutrient cycling, Appl. Environ. Microbiol. 63 (1997) 4408-4412.

[61] Toro N., Azcón R., Barea J.M., The use of isotopic dilution techniques to evaluate the interactive effects of Rhizobium genotype, mycorrhizal fungi, phosphate-solubilizing rhizobacteria and rock phosphate on nitrogen and phosphorus acquisition by Medicago sativa, New Phytol. 138 (1998) 265-273.

[62] Velázquez E., Cruz-Sánchez J.M., Mateos P.F., Martínez-Molina E., Analysis of stable low-molecular-weight RNA profiles of members of the family Rhizobiaceae, Appl. Environ. Microbiol. 64 (1998) 1555-1559.
[63] Velázquez E., Cervantes E., Igual J.M. et al., Analysis of LMW RNA profiles of Frankia strains by staircase electrophoresis, Syst. Appl. Microbiol. 21 (1988) 539-545.

[64] Velázquez E., Calvo O., Cervantes E., Mateos P.F., Tamame M., Martínez-Molina E., Staircase electrophoresis profiles of stable low-molecular-weight RNA - a new technique for yeast fingerprinting, Int. J. Syst. Evol. Microbiol. 50 (2000) 917-923.

[65] Velázquez E., Igual J.M., Willens A., Fernandez M.P., Muñoz E., Mateos P.F., Abril A., Toro N., Normand P., Cervantes E., Gillis M., Martínez-Molina E., Mesorhizobium chacoense sp. nov., a novel species that nodulates Prosopis alba in the Chaco Arido region (Argentina), Int. J. Syst. Evol. Microbiol. 51 (2001) 1011-1021.

[66] Versalovic J., Schneider M., de Bruijn F.J., Lupski J.R., Genomic fingerprinting of bacteria using repetitive sequences based on PCR (rep-PCR), Methods Mol. Cell. Biol. 5 (1994) 25-40.

[67] Weisburg W.G., Barns S.M., Pelletier D.A., Lane D.J., $16 \mathrm{~S}$ ribosomal DNA amplifications for phylogenetic study, J. Bacteriol. 43 (1991) 305-313.

[68] Woese C.R., Bacterial evolution, Microbiol. Rev. 51 (1987) 221-271.

To access this journal online: www.edpsciences.org 